\title{
EFFECT OF SUPPLEMENTATION OF MICRONUTRIENTS ON THE PERFORMANCE OF DAIRY COWS
}

\author{
M. M. Sharmin ${ }^{1}$, M. A. Samad Khan ${ }^{1}$, M. N. Islam ${ }^{1}$ and M. A. Islam ${ }^{2}$
}

\begin{abstract}
An experiment was conducted to study the effect of micronutrients supplementation on body weight of cows, birth weight of calf, colostrums composition, milk yield and milk composition. Six animals were divided in to two groups viz. control and supplemented group. Control group was provided conventional diet and supplemented group was supplied conventional diet plus vitamin-mineral mixture (1g vitamix powder $1 \mathrm{~kg}$ concentrate feed) respectively for two months before calving. In supplemented group the average daily gain of the cows was $(49.17 \mathrm{~g} / \mathrm{d})$ higher $(\mathrm{P}<0.01)$ and the calves were $2 \mathrm{~kg}$ heavier in supplemented group compared to control group. Fat content and protein content of colostrum in supplemented group were also significantly higher $(\mathrm{P}<0.01$ and 0.05 ). The milk yield, fat and protein values of milk were increased non-significantly by $1.03 \mathrm{~kg} / \mathrm{d} / \mathrm{h}, 2.8 \mathrm{~g} / \mathrm{kg}$ and $0.3 \mathrm{~g} / \mathrm{kg}$ respectively. Ca content of milk was more or less similar in both cases.
\end{abstract}

Key words: Milk, Milk protein, Milk fat, Micronutrients, Supplementation.

\section{Introduction}

Micronutrients are the elements required by the body in negligible amount for optimum growth and proper muscle and nerve function. In addition, they are essential components of body enzymes, hormones and cells. Recommended mineral levels are not constant; they vary with changing production, body size, environment and other dietary factors. The transition period for a dairy cow begins two to three weeks prepartum and continues until two to three weeks postpartum. During this period, the cow undergoes considerable stress as she prepares for and recovers from parturition. Micronutrients play a critical role in minimizing the negative effects of stress and it is important the cow has good reserves of minerals to help her through this period. Thus, it is important that cows have adequate micronutrients status during gestation and particularly immediately before parturition to avoid sub-clinical problems leading to decreased lactation performance or reproduction in the subsequent lactation. Mtui et al. (2007) suggested the need for supplementation of deficient minerals like $\mathrm{Cu}, \mathrm{Zn}$ and Se for optimal cows' productivity. In dairy cows, supplementation with complexed trace minerals increases-milk yield (16.6 vs $17.5 \mathrm{~kg} / \mathrm{d})$, milk fat $(0.73 \mathrm{vs} 0.78 \mathrm{~kg} / \mathrm{d})$ and milk CP (0.58 vs $0.62 \mathrm{~kg} / \mathrm{d})$ compared to control group (Griffith et al., 2007). The first

\footnotetext{
${ }^{1}$ Department of Dairy Science, Bangladesh Agricultural University, Mymensingh-2202, Bangladesh

${ }^{2}$ Department of Animal Nutrition, Bangladesh Agricultural University, Mymensingh-2202, Bangladesh
}

(Received: October 06, 2010) 
Bang. J. Anim. Sci. 2010, 39(1\&2)

calf heifers produced more milk and milk components with fewer open days (days from parturition to estrus) and better breeding efficiency, along with higher body condition scores, when supplemented with metal amino acid chelates (AACs) (Ashmead et al., 2004). Having considered the above points, the present research work was undertaken - To investigate the effect of micro-nutrients supplementation on body weight of cows and birth weight of calves and to know the effect of micro-nutrients supplementation on colostrum composition, milk yield and milk composition.

\section{Materials and Methods}

The present study was carried out at Department of Dairy Science, Bangladesh Agricultural University. Six pregnant cows (Sahiwal cross) of two to fifth lactation were used in this experiment for a period of 95 days (60 days before calving and 35 days after calving). Animals were divided into control group and supplemented groups. All the experimental animals were fed with green German (Echinoclora grousgally) and Para grass (Brachiaria mutica) on ad libitum basis, $1 \mathrm{~kg}$ of concentrate mixture/ head/ day and only the animals of supplemented group were provided with vitamin-mineral mixture $(1 \mathrm{~g} / \mathrm{kg}$ concentrate mixture). The concentrate mixture contained rice polish, wheat bran and til oil cake. Vitamin-mineral mixture (Composition per 500g Vitamix powder) contains Vitamin-A3000000 IU; Vitamin D 100000 I.U; Vitamin E - 50 mg; Co - 50 mg; Cu - 500 mg; Fe - 5 mg; Se - 15 mg; Mo - 50 mg; Mg - 25 mg; Mn - 205 mg; Zn - 2g; Ca - 130g and P - 32.5 g and I $-30 \mathrm{mg}$.

The pregnant cows were weighed individually to take the body weight. Colostrum samples from each calved cows were collected daily for first five days after calving and individual milk sample was collected just after complete milking at seven days interval for chemical analysis. Milk of the individual cow was recorded weekly. The colostrum samples were analyzed for fat and protein content and milk samples were analyzed for fat, protein and $\mathrm{Ca}$ content. Fat test was performed by Babcock fat test method and protein content was estimated by Kjeldhal method. Ca content was determined by Ethylene Diamine Tetra Acetate titrimetric method. The data were analyzed by using t-test.

\section{Results and Discussion}

\section{Colostrum composition}

There was significant difference $(\mathrm{P}<0.01$ and 0.05$)$ of fat content in control and supplemented group due to micronutrients supplementation (Table 1). The highest value was found at day 1 in both cases. According to Foley and Otterby (1978), the average fat content of cow colostrum at day 1 day, 2 day, 3 day, 4 day, and 5 day were 60.70, 50.40, 30.90, 40.40 and $40.30 \mathrm{~g} / \mathrm{kg}$, respectively which is almost similar to the results of the present work. 
Table 1. Fat and protein content of colostrums $(\mathrm{g} / \mathrm{kg})$

\begin{tabular}{|c|cc|c|c|}
\hline Days after calving & \multicolumn{2}{|c|}{ Treatments } & SEM & Level of Sig. \\
\hline \multicolumn{2}{|c|}{ Fat content of colostrum (g/kg) } & & & \\
1 & 51.30 & 55.70 & 0.08 & $* *$ \\
2 & 38.30 & 44.70 & 0.16 & $*$ \\
3 & 35.00 & 37.70 & 0.19 & $* *$ \\
4 & 33.70 & 36.00 & 0.09 & $* *$ \\
5 & 32.70 & 37.70 & 0.14 & $* *$ \\
\hline Average & 38.2 & 42.36 & 0.13 & \\
\hline Protein content of colostrum (g/kg) & & & $* *$ \\
1 & 116.10 & 123.20 & 0.31 & $*$ \\
2 & 58.50 & 59.10 & 0.60 & $*$ \\
3 & 33.40 & 33.60 & 0.20 & $* *$ \\
4 & 32.30 & 32.30 & 0.11 & \\
\hline 5 & 31.10 & 31.90 & 0.05 & \\
\hline Average & 54.28 & 56.02 & 0.25 & \\
\hline
\end{tabular}

SEM $=$ Standard error of means

$* *=\mathrm{P}<0.01 *=\mathrm{P}<0.05$, NS $=$ Non-significant

Average protein values of colostrum were higher in supplemented group (Table 1). There was significant difference $(\mathrm{P}<0.01$ and 0.05$)$ between the control and supplemented group due to micronutrients supplementation. Statistically non-significant difference was observed for the values at $2^{\text {nd }}$ day. The result is supported by Foley and Otterby (1978). They reported that the protein content of colostrum from 1day - 5day were 140.00, 80.40, 50.10, 40.20, 40.10 and $30.10 \mathrm{~g} / \mathrm{kg}$, respectively. The higher fat and protein content of colostrum might be due to better feed intake, nutrient availability and management condition.

\section{Body weight of cows and birth weight of calves}

The average values of body weight of cows and birth weight of calf were shown in table 2 . Tthere was significant difference $(\mathrm{P}<0.01)$ in body weight of cows. The average daily gain of the cows was $49.17 \mathrm{~g} / \mathrm{d}$ higher compared to control group $(\mathrm{P}<0.01)$. This might be due to increased nutrient availability of feed. Rekhis et al. (2002) reported that the body condition score of the cows was higher in the supplemented group than in the control group but the effect was not significant $(\mathrm{P}>0.05)$. Calves of supplemented group were on an average $2 \mathrm{~kg}$ heavier than that of control group. The non- significant difference for birth weight of calf in the present study corresponds with that found by Rekhis et al. (2002).

\section{Milk yield and milk composition}

In the present study the average milk yield was $1.03 \mathrm{~kg} / \mathrm{d}$ in supplemented group which was higher than the control group (Table 2). However, But, the result was non-significant. 
Bang. J. Anim. Sci. 2010, 39(1\&2)

Griffiths et al. (2007) explained that compared to the control, supplementing complexed trace mineral $(\mathrm{CTM})$ increased $(\mathrm{P} \leq 0.05)$ yield of milk. The findings of present study also agree with the results of Gowda et al. (2004); Boland et al. (1996) and Iwanska et al. (1999).

Table 2. Body weight, milk yield and milk composition

\begin{tabular}{|l|c|c|c|c|}
\hline \multirow{2}{*}{ Parameters } & \multicolumn{2}{c|}{ Treatments } & \multirow{2}{*}{ SEM } & \multirow{2}{*}{ Level of Sig. } \\
\cline { 2 - 3 } & Control & Supplement & & \\
\hline Daily body weight of cows $(\mathrm{g} / \mathrm{kg})$ & 137.16 & 186.33 & 2.78 & $* *$ \\
Birth wt of calf & 17.33 & 19.33 & 0.78 & $\mathrm{NS}$ \\
Milk yield (kg/d) & 3.07 & 4.10 & 0.68 & $\mathrm{NS}$ \\
Fat content of milk (g/kg) & 36.9 & 39.7 & 0.14 & $\mathrm{NS}$ \\
Protein content of milk $(\mathrm{g} / \mathrm{kg})$ & 31.3 & 31.6 & 0.085 & $\mathrm{NS}$ \\
Ca content of milk $(\mathrm{mg} / 100 \mathrm{ml})$ & 117.00 & 117.36 & 2.23 & $\mathrm{NS}$ \\
\hline
\end{tabular}

SEM $=$ Standard error of means

$* *=\mathrm{P}<0.01$, NS $=$ Non-significant

Milk fat content was $2.8 \mathrm{~g} / \mathrm{kg}$ which is higher compared to control group. However, the result was statistically non-significant. This finding was similar to Rekhis et al. (2002). They showed that micronutrients supplementation had a significant effect on calf weight, milk fat content and reproduction parameters. The findings of present study also agree with the results of Griffiths et al. (2007); Ashmead et al. (2004); Iwańska et al. (1999) and Boland et al. (1996). Average protein content was non-significantly higher in supplemented group compared to control group (Table 2). Boland et al. (1996) found that total protein yield were $57.3 \pm 2.8$ and $64.5 \pm 2.7 \mathrm{~kg}$ following a treatment for 12 weeks $(\mathrm{P}<0.03)$ in control and bioplex mineral supplemented group, respectively. The result of present study agrees with the work of Ashmead et al. (2004); Gowda et al. (2004) and Iwanska et al. (1999). Micronutrients help to improve the utilization of low quality forages. Because minerals specially P, Ca, Mn, Fe, Co, Mo, Mg etc are the key elements for the synthetic mechanism of milk carbohydrate, fat and protein. They are important to maximize the genetic potential of the animals in relation to production. Better utilization of roughages might be responsible for non-significantly increased milk yield, fat and protein value of milk. The average value of $\mathrm{Ca}$ content was non-significantly higher in supplemented group. The milk and dairy products contain around 1200-2500 mg of Ca/L of milk (Andrew et al., 1998). The result of the present study falls within the normal range. Because some literature says that mineral supplementation does not increase the specific mineral content of milk, while some explains the reversible result.

\section{Conclusion}

From the results of the present experiment, it may be concluded that the micronutrients supplementation improves the body weight of pregnant cows, fat and protein content of colostrums. 
Micronutrients supplementation on dairy cows diet

\section{Literature Cited}

Andrew, W. L. and Kate, W. B. 1998. Milk and Milk Products. Agro-botanical Publishers (India), pp. 30-31

Ashmead, H. D., Ashmead, S. D. and Samford, R. A. 2004. Effects of metal amino acid chelates on milk production, reproduction, and body condition in Holstein first calf heifers. Intl. J. Appl. Res. Vet. Med., 2(4): 252-260.

Bis, H. 2003. Mineral elements level in milk of the cows with mineral dietary supplementation. Annales Universitatis Mariae Curie Sklodowska Sectio EE Zootechnica, 21(2): 259-264.

Boland, M. P., O’Donnell, G. and O’Callaghan, D. 1996. The contribution of mineral proteinates to production and reproduction in dairy cattle. In: Biotechnology in the feed industry. Ptoc Alltech's $12^{\text {th }}$ Annual Symp. pp. 95-103.

Gowda, N. K. S., Prasad, C. S. and Ramana, J. V. 2004. Effect of supplementation of micronutrients through different sources on the production performance in crossbred dairy cows. Indian J. Anim. Sci., 74(6): 653-657.

Griffiths, L. M., Loeffler, S. H., Socha, M. T., Tomlinson, M. T. and Johnson A. B. 2007. Effects of supplementing complexed zinc, manganese, copper and cobalt on lactation and reproductive performance of intensively grazed lactating dairy cattle on the South Island of New Zealand. Anim. Feed Sci. and Technol. , 137(1-2): 69-83.

Iwanska, S., Strusińska, D., Zalewski, W. and Opałka, A. 1999. The effect of Saccharomyces cerevisiae1026 used alone or with vitamin-mineral premix on milk yield and milk composition in dairy cows. Acta Vet Hung, 47(1): 41-52.

Mtui, D. J., Mellau, L. S. B., Lekule, F. P., Shem, M. N., Hayashida, M. and Fujihara, T. 2007. Seasonal influence on mineral concentrations in dairy cows' blood and feed resources collected from Morogoro, Tanzania. J. Food, Ag. Environ., 5(3/4): 274-280.

Rekhis, J., Kouki, C.K. and Khlif, K. 2002. Mineral supplementation in Tunisian smallholder dairy farms. International Atomic Energy Agency Technical Documents. IAEA. TECDOCs, 1294: 97-101. 